\title{
TRADISI NUJUH BULAN PADA MASYARAKAT MUSLIM MELAYU KABUPATEN MELAWI
}

\author{
Buhori; Hanna Yulia; Velly Pranika Sari \\ Fakultas Ushuluddin, Adab dan Dakwah (FUAD) \\ Institut Agama Islam Negeri (IAIN) Pontianak \\ E-mail : kanghari32@yahoo.co.id; hannayulia90@gmail.com; vellypranika@ gmail.com
}

\begin{abstract}
One of the customs commonly practiced by Malay tribes, especially Malay tribes in Melawi Regency is seventh month's ritual or in local language called Nujuh Bulan. Based on the results of studies in the field, it can be concluded that: 1) This tradition is a ceremony performed by the owner as a form of gratitude towards Allah SWT for the first pregnancy of a wife; 2) Seven Months are usually performed at the gestational age of a woman of sixteen weeks or twenty-eight weeks; 3) This event is usually carried out by giving prayers to Allah SWT and alms that will be given to invited guests, which are attended by orphans, neighbors, and closest families.

Salah satu adat istiadat yang biasa dilakukan oleh suku Melayu khususnya suku Melayu yang ada di Kabupatan Melawi adalah tujuh bulanan atau dalam bahasa setempat disebut Nujuh Bulan. Berdasarkan hasil kajian di lapangan, dapat disimpulkan bahwa: 1) Tradisi ini merupakan upacara yang dilakukan oleh empunya hajat sebagai bentuk rasa syukur terhadap Allah SWT atas kehamilan pertama seorang istri; 2) Nujuh Bulan biasanya dilakukan saat usia kehamilan seorang wanita berumur enam belas minggu atau dua puluh delapan minggu; 3) Acara ini biasanya dilakukan dengan cara memanjatkan do'a-do'a kepada Allah SWT dan sedekah yang akan diberikan kepada tamu undangan, yang dihadiri oleh anak-anak yatim, tetangga sekitar, dan keluarga terdekat.
\end{abstract}

Kata Kunci: Nujuh Bulan, Muslim Melayu Melawi

\section{PENDAHULUAN}

Budaya dan agama merupakan dua hal yang saling mempengaruhi. Ketika agama Islam yang berasal dari Jazirah Arab semakin tersebar luas dan akhirnya sampai ke Indonesia termasuk Kalimantan Barat maka akan terjadi penyesuaian antara budaya yang 'memasuki' dan 'dimasuki'. Hal tersebut terjadi karena adanya tarik-menarik antara kepentingan agama di satu sisi dan kepentingan budaya di sisi lain. Indonesia sebagai Negara pemeluk Islam terbesar di dunia merupakan Negara yang terdiri dari berbagai suku, diantaranya adalah suku Melayu. Suku Melayu merupakan suku yang sebagian besar dari masyarakatnya memeluk agama Islam. Maka tidak heran lagi jika kita menemukan beberapa adat istiadat yang dilakukan oleh suku Melayu berkaitan dengan ajaran Islam. 
Masyarakat Indonesia sangat kaya dalam masalah budaya, tradisi, dan kearifan lokal. Budaya maupun tradisi lokal pada masyarakat Indonesia tidak hanya memberikan warna dalam persaturan kenegaraan, tetapi juga berpengaruh dalam keyakinan dan praktik-praktik keagamaan masyarakat. Islam, sebagai sebuah agama yang dianut oleh mayoritas masyarakat Indonesia, memiliki hubungan erat dengan kebudayaan atau tradisi-tradisi lokal yang ada di nusantara. Hubungan antara Islam dengan isu-isu lokal adalah kegairahan yang tak pernah usai. Hubungan intim antara keduanya dipicu oleh kegairahan pengikut Islam yang mengimani agamanya: shalihun li kulli zaman wa makan selalu baik untuk setiap waktu dan tempat ${ }^{1}$.

Maka ajaran Islam yang datang ke suatu tempat akan senatiasa dihadirkan dan diajak bersentuhan dengan keanekaragaman konteks budaya setempat. Dalam ungkapan lain dapat dikatakan bahwa Islam tidak datang ke sebuah tempat, dan di suatu masa yang hampa budaya. Melainkan Islam datang di suatu tempat dan di suatu masa yang sudah memiliki budaya yang menjadi khas dari tempat tersebut.

1 Buhori, Islam dan Tradisi Lokal di Nusantara, (Pontianak: Jurnal Al-Maslahah Vol 13, No.2 IAIN Pontianak, 2017), hlm.230
Islam yang hadir di Indonesia juga tidak bisa dilepaskan dengan budaya dan tradisi yang melekat erat pada masyarakat Indonesia. Sama seperti Islam di kawasan Arab, Arabisme dan Islamisme bergumul sedemikian rupa di kawasan Timur Tengah sehingga kadang-kadang orang sulit membedakan mana yang nilai Islam dan mana yang simbol budaya Arab. Nabi Muhammad saw, tentu saja dengan bimbingan Allah (wama yanthiqu 'anil hawa, in hua illa wahyun yuha ${ }^{2}$ ), dengan cukup cerdik (fathanah) mengetahui sosiologi masyarakat Arab pada saat itu. Sehingga beliau dengan menggunakan tradisi-tradisi Arab untuk mengembangkan Islam. Sebagai salah satu contoh misalnya, ketika Nabi Muhammad Saw. hijrah ke Madinah, masyarakat Madinah di sana menyambut dengan iringan gendang dan tetabuhan sambil menyanyikan thala'albadru alaina dan seterusnya. Hal ini menandakan bahwa pada saat itu masyarakat Madinah telah memiliki tradisi dan budaya yang melekat erat dalam kehidupan mereka. Budaya dalam penyambutan tamu agung yang dihormati dengan sambutan tabuhan gendang.

2 QS. An-Najm (53): 3-4, Al-Qur'an dan Terjemahan, Al-Hikmah (Bandung: Penerbit Diponegoro, 2008). 


\section{Al-Hikmah: Jurnal Dakwah, Volume 12, Nomor 1, Tahun 2018 \\ [P. 83-100]}

Dalam artikel ini penulis akan mencoba menguraikan sikap akomodatif ajaran Islam terhadap budaya lokal dalam konteks kehidupan keberagamaan pada sebagian besar masyarakat di nusantara ini, sebagai salah satu contoh yaitu tradisi yang lazim dilakukan oleh masyarakat Melayu Kabupaten Melawi yaitu Nujuh Bulan. Penulis akan mencoba mengupas pandangan Islam mengenai tradisi tersebut.Tujuan dari pembahasan dalam artikel ini adalah untuk mendeskripsikan dan memberikan informasi yang akurat terkait prosesi Nujuh Bulan baik itu dari segi prosesinya, adat-istiadat nya, maupun hukum atau perspektif Islam mengenai acara tersebut. Agar terjadinya keselarasan anantara budaya dan agama Islam. Juga demi terjaganya budaya dan kearifan lokal untuk generasi mendatang.

Metode penelitian yang digunakan untuk mengetahui dinamika dan pengaruh budaya Melayu di Kalimantan Barat adalah dengan studi kepustakaan, berupa penelaahan dan dan analisa buku, artikel dan bentuk tulisan lainnya yang mendukung penelitian ini serta sumber-sumber lokal tersebut. Data dan informasi yang didapat, diolah dengan pendekatan kualitatif sesuai dengan metode tersebut yang tentunya mampu merekontruksikan dan meninjau tradisi nujuh bulan pada masyarakat Melayu Kabupaten Melawi dalam perspektif Islam.

\section{Keberagaman Tradisi Muslim di Indonesia}

\section{Budaya dan Tradisi}

Sebelum penulis membahas lebih jauh mengenai apa itu tradisi Nujuh Bulan pada masyarakat Melayu penulis terlebih dahulu akan memaparkan mengenai ulasan tentang budaya dan tradisi.

Secara epistimologi atau secara bahasa kata budaya berasal dari kata budi dan daya. Budi berarti akal, kecerdikan, kepintaran dan kebijaksanaan, sedangkan Daya memiliki arti ikhtiar, usaha atau muslihat. Dedi Supriyadi (2008:16) mengartikan bahwa budaya (culture) dapat dipahami sebagai pembangunan yang didasarkan atas kekuatan manusia, baik pembangunan jiwa, pikiran dan semangat melalui latihan dan pengalaman, bukti nyata pembangunan intelektual seperti seni dan pengetahuan. Dengan demikian secara singkat dan sederhana, sebagaimana dipahami secara umum, kebudayaan 
merupakan semua hasil karya, rasa dan cipta masyarakat ${ }^{3}$.

Salah satu bagian dari budaya adalah tradisi. Dalam Kamus Besar Bahasa Indonesia tradisi diartikan sebagai adat kebiasaan turun-temurun (dari nenek moyang) yang masih dijalankan dalam masyarakat; atau juga penilaian atau anggapan bahwa caracara yang telah ada merupakan yang paling baik dan benar ${ }^{4}$.

Terminologi tradisi, yang berasal dari kata bahasa Inggris tradition, sering juga disamakan dengan lafadz 'ãdah dalam bahasa Arab. Kata 'ãdah ini dipergunakan untuk menunjuk desain atau pola perilaku dan kegiatan tertentu menurut standar baku dalam bidangnya masing-masing yang sering dilakukan oleh masyarakat.

Al-'ãdah yang secara literal berarti kebiasaan dapat dibedakan menjadi dua bagian, yaitu al- 'ãdah asshãhihah (tradisi yang baik) dan al'ãdah al-fãsidah (tradisi yang buruk). Dalam konstruksi hukum Islam, al-

\footnotetext{
${ }^{3}$ Dedi Supriyadi, Sejarah Peradaban Islam, (Bandung: Pustaka Setia, 2008), hlm. 16.

4 Departemen Pendidikan Nasional, Kamus Besar Bahasa Indonesia, (Jakarta: Pusat Bahasa, 2008), 1543.
}

'ãdah as-shãhihah (tradisi yang baik) dapat dipertimbangkan sebagai salah satu rujukan dalam penetapan hukum Islam. Terdapat suatu kaidah yang populer di kalangan ulama ushûliyyin: al-'ãdah muhakkamah yang berarti tradisi dapat dijadikan sebagai sumber hukum. Kendatipun demikian, kaidah tersebut tidak dapat di generalisir pada setiap persoalan. Kaidah tersebut tidak dapat diberlakukan apabila :

a. Al- adah bertentangan dengan nash Al-qur'an dan hadis, seperti: puasa sehari semalam, kebiasaan menanam kepala hewan kurban waktu membuat jembatan. Kebiasaan memelihara babi, dan lain sebagainya.

b. Al- a dah tersebut menyebabkan kemafsadatan atau menghilangkan kemashlahatan termasuk di dalamnya tidak mengakibatkan kesulitan atau kerusakan, seperti: menghamburhamburkan harta, hura-hura dalam perayaan dan lain-lain.

c. Al- adah berlaku secara umum di kalangan kaum muslimin, dalam arti bukan hanya yang bisa dilakukan oleh beberapa orang saja. Bila dilakukan oleh beberapa orang saja maka tidak dianggap adat. 


\section{Al-Hikmah: Jurnal Dakwah, Volume 12, Nomor I, Tahun 2018 \\ [P. 83-100]}

Ibnu Taimiyah menyatakan bahwa ibadah mahdhah tidak dilakukan kecuali yang disyari'atkan Allah dan aladah tidak diharamkan kecuali yang diharamkan Allah. Manusia dalam kehidupannya akan senantiasa mengadakan proses interaksi dan proses sosial lainnya, sehingga tumbuh normanorma kelompok dan akhirnya melembaga sehingga tampil struktur sosial dalam himpunan kelompok tersebut. Norma-norma yang dihasilkan dari hasil karya, cipta dan karsa manusia ini senantiasa dilakukan secara berulang-ulang dan cendrung untuk diwariskan secara turun temurun kepada generasi berikutnya, untuk kemudian menjadi sebuah tradisi yang melekat erat dalam kehidupan mereka. Dalam hal ini, tradisi merupakan sub-sistem dari norma sosial masyarakat yang melahirkan kelompok tersebut.

Namun, perlu juga ditegaskan di sini bahwa agama bukanlah kebudayaan maupun tradisi, karena agama itu diciptakan Tuhan, bukan hasil olah pikir dan karya manusia. Tetapi kelompokkelompok orang beragama membentuk kebudayaan dan juga tradisi mereka masing-masing sebab mereka mempunyai budaya dan kebiasaankebiasaan yang dilakukan secara terus menerus dalam kehidupannya.

Oleh sebab itu, pada hakikatnya tidak ada kebudayaan Islam atau tradisi Islam, namun yang ada adalah kebudayaan dan tradisi orang Islam, karna Islam itu bukan kebudayaan dan tradisi melainkan ciptaan Tuhan Yang Maha Esa. Kebiasaan yang diwariskan secara turun-temurun oleh orang Islam sebagai kelompok masyarakat, dan berlanjut serta dilestarikan hingga saat ini kemudian melembaga di tengah masyarakat itulah yang kemudian dikenal dengan sebutan kebudayaan atau tradisi Islam, yang berarti kebudayaan dan tradisi orang Islam ${ }^{5}$.

\section{Keberagamaan Muslim Indonesia}

Terminologi keberagamaan perlu dibedakan dengan term agama atau keagamaan. Di satu sisi, keagamaan berasal dari akar kata agama yang menunjuk pada seperangkat wahyu ketuhanan agar menjadi petunjuk kehidupan orang yang beriman untuk mewujudkan kebahagiaan dunia dan akherat. Di sisi lain, keberagamaan merupakan kata benda dari akar kata

\footnotetext{
${ }^{5}$ Siradjuddin Abbas, 40 Masalah Agama 3, (Jakarta: Pustaka Tarbiyah Baru, 2012),.hlm. 291.
} 
"beragama". Kata kerja beragama, menunjuk pada produk kegiatan berikut segala aktifitas melaksanakan substansi ajaran agama oleh orang-orang yang beriman sesuai dengan materi ajaran tersebut ${ }^{6}$.

Dengan demikian, kandungan pengertian keberagamaan selalu berkaitan dengan kekhususan kelompok pemeluk agama, jika dibandingkan dengan himpunan manusia pada umumnya. Dalam posisi ini, himpunan orang beragama atau para pemeluk agama tersebut merupakan unit sosial yang memiliki kesadaran diri bertumpu pada jati dirinya sendiri. Maka, pada fenomena ini lahirlah komunitas keberagamaan yang memiliki karakterisitk atau ciri tertentu.

Agama Islam yang bersumber dari al-Qur'an dan Sunnah dan diyakini sebagai kebenaran tunggal oleh pemeluknya. Akan tetapi, pada saat ajaran yang bersifat transenden ini mulai bersentuhan dengan kehidupan manusia, serta aspek sosiokultural yang melingkupinya, maka terjadilah berbagai penafsiran yang cendrung berbeda dan berubah-ubah. Hal ini akibat perbedaan kehidupan sosial penganut

\footnotetext{
${ }^{6}$ Muslim A. Kadir, Dasar-Dasar Keberagamaan dalam Islam (Yoyakarta: Pustaka Pelajar, 2011), hlm. 56.
}

yang juga terus berubah. Dari perbedaan penafsiran itu lahirlah kemudian pemikiranpemikiran dalam bidang fiqh dan teologi yang berbeda. Selain itu, realitas ini pula yang pada akhirnya melahirkan tradisi keberagamaan kaum muslimin, yang masing-masing menampakkan ciri khas dari kehidupannya. Hal tersebut di atas menandakan bahwa meskipun Islam itu satu dari sudut ajaran pokoknya, akan tetapi setelah "terlempar" dalam konteks sosiokultural-politik tertentu pada tingkat perkembangan sejarah tertentu pula agama bisa memperlihatkan struktur internal yang berbeda-beda.

Kelompok tradisionalis sering dikategorikan sebagai kelompok Islam yang masih mempraktikkan beberapa praktik tahayyul, bid'ah, khurafat, dan beberapa budaya animisme, atau sering diidentikkan dengan ekspresi Islam lokal, sementara kelompok modernis adalah mereka yang sudah tidak lagi mempraktikkan beberapa hal di atas. Akan tetapi kategorisasi dan polarisasi ini menjadi kurang tepat ketika ditemukan adanya praktik budaya animisme yang dilakukan oleh kalangan muslim modernis. Selain itu, klaim Islam tradisional sebagai pelaku tahayul, bid ah dan khurafat dewasa ini kurang menemukan pijakannya. Sebab kalangan muslim tradisional bukanlah 


\section{Al-Hikmah: Jurnal Dakwah, Volume 12, Nomor I, Tahun 2018 \\ [P. 83-100]}

pelaku perbuatan itu, karna memang dalam ajaran Islam perbuatan-perbuatan yang menjurus kepada Tahayyul, bid`ah dan khurafat sangat dilarang. Melainkan Islam tradisionalis lebih menekankan kepada kesadaran untuk menghargai tradisi dan budaya yang sudah ada di tengah masyarakat.

Tradisi keberagamaan yang berkembang di kalangan Islam tradisionalis tampak lebih toleran terhadap nilai-nilai tradisi dan budaya lokal setempat. Kalangan ini meyakini, ajaran Islam datang dan tersebar ke penjuru dunia, bukan untuk mengganti budaya dan tradisi yang ada dengan tradisi dan budaya Arab sebagai tempat awal diutusnya nabi Muhammad SAW sang pembawa risalah Islam. Akan tetapi Islam hadir dengan membawa risalah ilahiyah yang sangat menghargai nilai-nilai tradisi dan budaya setempat, selama ia membawa hal positif dalam kehidupan manusia dan tidak bertentangan dengan prinsip ajaran Islam.

Ajaran Islam juga tidak mengharamkan orang-orang Islam untuk berbudaya dan beradat istiadat sesuai dengan kulturnya, karna budaya merupakan bagian dari kehidupan manusia yang tidak dapat dipisahkan, selama ia hidup di dunia ini. Selama tradisi dan budaya itu tidak bertentangan dengan syari’at Islam yang telah ditetapkan, maka sah-sah saja untuk tetap dilaksanakan dan dilestarikan.

Dalam konteks ini pula kita dapat memahami arah dari terma Islam Nusantara. Sebuah istilah yang sejak digulirkan dan dipopulerkan sempat menimbulkan pro kontra bagi sebagian masyarakat Islam Indonesia. Islam Nusantara bukanlah sebuah aliran atau sekte baru, bukan pula sebagai ajaran baru dalam agama, bahkan sangat tidak mungkin sebagai agama baru seperti yang banyak disalahpahami oleh kelompok tertentu selama ini. Namun ia lebih mengarah sebagai khasaish, karakteristik khusus dan bentuk ciri khas keberagamaan muslim di Nusantara, serta pola dakwah yang dilakukan oleh para pembawa risalah Islam ke Nusantara yang begitu adaptif terhadap budaya-budaya lokal di Nusantara dengan tetap berlandaskan pada satu landasan, yakni Al-qur`an dan Sunnah. Afifuddin Muhajir memberikan ulasan singkat tentang Islam Nusantara dengan rumusan praktik keislaman di bumi Nusantara sebagai hasil dialektika antara 
teks syari’at dengan realita dan budaya setempat ${ }^{7}$.

Memang betul Islam itu hanya satu dan memiliki landasan yang satu. Akan tetapi selain memiliki landasan nash-nash syari`at (al-Qur`an dan Sunnah), Islam juga memiliki acuan maqashid syarìa (tujuan syari`at). Dibalik aturan-aturan syari`at Islam ada tujuan yang hendak dicapai, yaitu terwujudnya kemaslahatan umat manusia di dunia dan akhirat. Aspek kemaslahatan ini dapat dirangkum dalam lima prinsip pokok (al-kulliyãt al-khoms), yaitu terpeliharanya agama (hifzhu ad-din), terpeliharanya diri/jiwa (hifzhu an-nafsh), terpeliharanya akal (hifzhu al-`aql), terpeliharanya harta (hifzhu al-mal), dan terpeliharanya keturuan (hifzhu an-nashl). Pada titik inilah terjadi persinggungan antara teks-teks syar’i yang bersifat sakral dengan sosiokultural kehidupan manusia yang profan. Hasil pergumulan ini yang selanjutnya menimbulkan pola keberagamaan tertentu pada sisi-sisi yang profan (bersifat furui yyah) dan menjadi wilayah kekhasan pada Islam Nusantara.

7 Lihat Ahmad Baso, Islam Nusantara, Ijtihad Jenius \& Ijma Ulama Indonesia. Jilid I, (Tangerang: Pustaka Afid, 2015), hal. xvi
Prosesi Nujuh Bulan, Acara Adat Kehamilan Masyarakat Melayu di Kabupaten Melawi

Kalimantan Barat sebagai provinsi dengan penduduk yang multi etnis dan multi kultural banyak memiliki kekayaan tradisi dan budaya lokal, sebagai buah dari peradaban kehidupan masyarakat setempat. Di antara sekian daerah yang berada di wilayah pemerintahan Kalimantan Barat adalah Kabupaten Melawi. Secara geografis, Kabupaten Melawi ini berbatasan langsung dengan Kabupaten Kota Waringin Timur Kalimantan Tengah. Kabupaten dengan luas wilayah 10.640,80 km. ini didiami oleh penduduk yang heterogen dengan mayoritas dari suku Melayu dan Dayak.

Salah satu tradisi lokal yang tidak asing lagi bagi masyarakat Melayu Kabupaten Melawi adalah Nujuh Bulan. Nujuh Bulan adalah serangkaian prosesi adat khas suku Melayu yang ada di Kabupaten Melawi dalam rangka mengungkapkan rasa syukur atas kehamilan pertama seorang istri.

Dalam bahasa Indonesia nujuh bulan sama artinya dengan tujuh bulanan. Dalam bahasa Melawi nya nujuh bulan. Acara tersebut dilakasanakan pada usia kehamilan tujuh bulan dan pada kehamilan pertama seorang wanita. Dalam acara ini sang ibu yang sedang hamil dibacakan doa bertujuan 


\section{Al-Hikmah: Jurnal Dakwah, Volume 12, Nomor I, Tahun 2018 \\ [P. 83-100]}

untuk memohon kepada Allah swt agar selalu diberikan rahmat dan berkah sehingga si cabang bayi yang akan dilahirkan selamat dan sehat. Tradisi ini identik dengan prosesi Pelet Kandhung atau Peret Kandung atau Salameddhen Kandhungan, yang dikenal pada masyarakat Madura. Ia juga memiliki kemiripan dengan istilah Tingkeban pada masyarakat Jawa yang merujuk pada tradisi peringatan atau syukuran atas kehamilan seorang istri.

Acara nujuh bulan tidak asing lagi bagi masyarakat Indonesia karena acara ini dilakukan oleh banyak suku bukan hanya suku Melayu saja melainkan suku lainnya juga, yang menjadi perbedaannya hanya nama dan prosesinya saja. Walaupun memiliki nama dan prosesi yang berbedabeda tetapi, tujuannya sama yaitu untuk mensyukuri dan mendoakan kehamilan pertama bagi seorang ibu. Agar saat kelahiran diberikan kelancaran dalam persalinan nanti

Kata "nujuh bulan" berasal dari bahasa Melayu yang artinya tujuh bulan. Hal ini berarti acara nujuh bulan dilakukan pada saat usia kehamilan seorang istri berusia tujuh bulan atau sekitar dua puluh delapan minggu.
Rangkaian prosesi Nujuh Bulan di kalangan Melayu Melawi dapat digambarkan sebagai berikut:

1. Pembacaan Do'a

Acara Nujuh Bulan biasanya dilakukan dengan pembacaan do'a-do'a dari Ustadz atau tetua-tetua sekitar. Do'ado'a yang biasa dibacakan adalah do'a selamat, do'a memohon ampunan, dan do'a-do'a baik lainnya sebagai bentuk rasa syukur.

Dalam proses Nujuh Bulan biasanya para tamu undangan bersamasama membacakan surah Maryam, atau surah Yusuf. Surah Maryam dibacakan apabila si empunya hajat ingin memiliki anak pertama berjenis kelamin perempuan, apabila menginginkan anak laki-laki maka yang dibaca adalah surah Yusuf. Masyarakat percaya dengan memperbanyak mengulang bacaan dari salah satu surah tersebut maka, InsyaAllah hajat ingin memiliki anak lelaki atau perempuan anak terkabul.

Hakikatnya, acara ini dilakukan agar proses kehamilan berjalan lancar. Anak yang ada di kandungan menjadi anak yang sholeh atau sholehah. Serta calon ibu yang sedang hamil diberi kesehatan dan proses persalinan nanti 
berjalan dengan lancar. Acara nujuh bulan, seperti yang dituliskan pada halaman sebelumnya biasa di hadiri oleh anak-anak yatim piatu, tetangga sekitar rumah, dan keluarga terdekat yang memiliki hajat. Selain itu, biasanya para sesepuh dan ustadz yang ada di kampung juga turut di undang.

2. Duduk di atas Tempayan dan Penaburan Beras Kuning

Setelah dilakukan proses pembacaan do'a maka calon ibu dan cabang bayi nya akan dipersilahkan duduk di atas tempayan. Tempayan yang dimaksud adalah semacam guci yang besar dan terbuat dari tanah. Tempayan biasanya diisi dengan bunga dan wewangian. Setelah sang calon ibu duduk maka akan di kelikingi oleh orang tua atau sesepuh kampung yang sudah menggenggam beras kuning.

Selanjutnya, para tetua dan sesepuh kampung satu persatu akan mengelilingi calon ibu seraya menaburkan beras kuning dan sambil mengucapkan do'a-do'a baik bagi si cabang bayi agar lahir menjadi anak yang sholeh/sholehah dan menjadi kebanggan kedua orang tua juga bagi si calon ibu agar diberikan kelancara selama proses persalinan dan juga untuk diberi kekuatan dan kesabaran dalam memomong anak kedepannya.

a. Memercikkan Air Kelapa Muda

Sesaat setelah calon ibu dan cabang bayi di taburi oleh beras kuning, maka prosesi selanjutnya adalah memercikkan air kelapa muda ke bagian perut si calon ibu. Buah kelapa yang masih muda menjadi simbol kesuburan, airnya lambang dari keselamatan maka kelapa muda tadi akan di belah menjadi dua dan airnya percikkan ke perut sang calon ibu menggunakan tangan secara langsug, atau daun pandan, atau janur yang masih muda.

Seperti proses sebelumnya, hal ini hanya di lakukan oleh orang tua atau sesepuh kampung sambil membacakan sholawat, do'a-do'a kebaikan bagi si cabang bayi dan ibu yang akan melahirkannya. Biasanya juga kedua proses diatas diiringi dengan tabuhan gendang yang dilakukan oleh majelis yang bisa memainkannya sembari bersholawat.

b. Penjamuan Makan

Disetiap acara hajatan, sang pemilik hajat tentu memberikan suguhan hidangan yang baik-baik dan sudah 


\section{Al-Hikmah: Jurnal Dakwah, Volume 12, Nomor I, Tahun 2018 \\ [P. 83-100]}

di siapkan oleh pemilik hajat. Hidangan yang biasa di sajikan secara prasmanan. Hidangan dapat berupa lauk-pauk, sayuran, dan nasi sebagai makanan pokok. Sebagai hidangan penutup atau pencuci mulut biasanya disediakan buah-buahan dan kue. Kue yang biasanya dihidangkan adalah kue-kue tradisional, misalnya bolu, apam pulut atau apam beras, juadah Belitung (dodol khas Melawi) dan berbagai hidangan lainnya.

Saat makan, biasanya para tamu undangan dipersilahkan untuk mengambil hidangannya sendiri yang telah disediakan oleh tuan rumah. Kemudian para tamu undangan makan bersama-sama sambil mengobrol, dan bersenda gurau antar yang satu dengan yang lainnya.

\section{c. Pemberian Souvenir}

Selain diberi jamuan makan dengan makanan pokok dan kue-kue jajanan tradisional. Setelah selesai acara, saat para tamu undangan hendak meninggalkan rumah tempat hajatan. Sang empunya hajat akan memberikan souvenir atau buah tangan sebegai oleh-oleh tanda terimakasih karena sudah menghadiri acara tersebut. oleh-oleh tersebut biasanya berupa gelas yang didalamnya diberi daun pandan dan bunga-bunga lainnya serta sebutir telur yang sudah direbus. Kemudian souvenir tersebut dibungkus dengan kain yang berbentuk seperti renda dan warna-warni untuk memperindah kemasan oleh-oleh tersebut.

\section{Nujuh Bulan dalam Perspektif Islam}

Nujuh Bulan sebagai tradisi yang lahir dari masyarakat Melayu Melawi dan diwariskan secara turun temurun sampai generasi yang hidup saat ini menjadi bukti adanya pergumulan antara upaya pengamalan nilainilai ajaran Islam dengan warisan tradisi setempat. Peringatan kehamilan sebagai bentuk syukur atas kehamilan istri dan pengharapan yang besar akan keselamatan anak dalam kandungan dan calon ibunya ditengarai sebagai tradisi yang telah berlangsung cukup lama, bahkan sebelum ajaran Islam datang di bumi Nusantara.

Hampir bisa dipastikan, pada awalnya sederet rangkaian prosesi Nujuh Bulan tidak berisikan dengan nilai-nilai syari`t Islam. Karena pada saat itu, 
masyarakat Nusantara belum mengenal dan mengamalkan ajaran Islam. Setelah para penyebar ajaran Islam sampai ke Nusantara, mereka tidak melarang dan menghilangkan tradisi yang ada, akan tetapi memilih untuk tetap memperhatikannya dan memberikan warna islami pada setiap prosesi yang dilakukan. Sebuah sikap yang bijaksana, dengan tetap mempertahankan kemasan, namun mengganti isinya sesuai dengan syari at Islam.

Islam sangat memperhatikan tradisi dan konvensi masyarakat untuk dijadikan sumber bagi hukum Islam dengar penyempurnaan dan batasan-batasan tertentu. Prinsip demikian banyak diajarkan oleh Nabi Muhammad SAW. Kebijakankebijakan beliau yang berkaitan dengan hukum yang tertuang dalam sunnahnya banyak mencerminkan kearifan beliau terhadap tradisi-tradisi para sahabat atau kaum muslimin kala itu.

Kebijakan dan kearifan Nabi Muhammad saw. dalam menyikapi tradisi yang ada dapat tergambar pada hadits berikut:

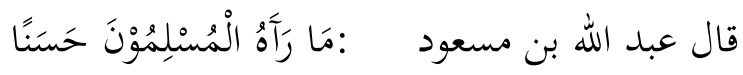

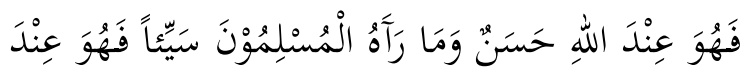

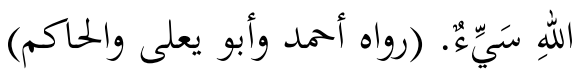

"Dicertikana kepada kami `Amr bin Hafs as-Sudusi, menceritakan 'Ashim in Ali, menceritakan al-Mas`udy, dari 'Ashim dari Abi Waildari Abdilah bin Mas`ud ia berkata: ... Apa yang dipandang baik oleh orang-orang mukmin, maka ia di sisi Allah pun baik, dan apa saja yang dipandang buruk oleh orang-orang mukmin, maka buruk pula ia di sisi Allah" (HR. Ahmad, Abu Ya'la dan al-Hakim).

Hadits tersebut oleh kalangan ushuliyyin dipahami (dijadikan dasar) bahwa tradisi masyarakat yang tidak bertentangan dengan prinsip-prinsip syari'at Islam dapat dijadikan dasar petimbangan dalam menetapkan hukum Islam (fiqih). Berdasarkan hadits tersebut kemudian dirumuskan suatu kaidah dalam ushul fiqh yang juga mendukung masuknya budaya dan tradisi dalam ajaran Islam yang berarti العادة محكمة adat/tradisi itu dapat dijadikan sebagai hukum". Adat dalam kaidah fiqh di atas secara bahasa berarti mu'awadatus syai'i wa tikroruhu (membiasakan sesuatu dan mengulang-ulangnya). Dalam hal ini maka adat memiliki kesamaan makna dengan 'uruf. Oleh sebab itu, dari sisi terminologi adat tersebut didefinisikan sebagai sesuatu yang telah masyhur di kalangan masyarakat 


\section{Al-Hikmah: Jurnal Dakwah, Volume 12, Nomor I, Tahun 2018 \\ [P. 83-100]}

dan telah dikenal secara luas, serta tidak bertentangan dengan syari at Islam ${ }^{8}$.

Rumusan ulama ushûl ini kembali menegaskan akan begitu besarnya perhatian Islam terhadap keberlangsungan sebuah tradisi. Ajaran Islam sangat mengapresiasi sebuah tradisi sebagai hasil karya dan cipta manusia dalam menjalani kehidupan sebagai khalifah fi al-ardh. Ajaran Islam tidak alergi dengan tradisi yang ada, kendatipun ia bukan merupakan produk orang-orang Islam dan tidak berasal dari bumi Arab, sebagai tempat kelahiran ajaran Islam pertama. Selama tradisi ini dapat dikompromikan dengan ajaran Islam, ritual yang bertentangan dengan ajaran Islam dapat diganti dengan amalan-amalan yang islami, maka selama itu pula Islam memberikan ruang kepadanya untuk tetap terus berlangsung, diamalkan dan diwariskan kepada generasi berikutnya.

Syari at Islam tidak hanya melihat pada kemasan, akan tetapi juga sangat konsen pada aspek isi/konten dalam kemasan. Dalam kaidah Ushul Fiqh dijelaskan:

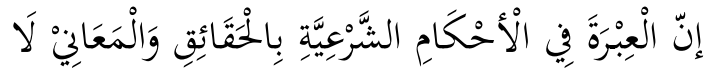

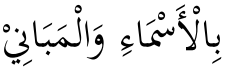

${ }^{8}$ Riyadh bin Mansur al-Akholifi, Al-Mihhaj fi ‘imil Qowa'id alFiqhiyyah, Juz 1 (Maktabah Syamilah, Isdor Tsnai), hlm. 10.
Barometer dalam penetapan hukum Islam adalah dengan melihat subtansi dan makna, bukan pada nama dan format (kemasan) ${ }^{9}$.

Manusia diciptakan dari jenis kelamin laki-laki dan perempuan, dari perbedaan jenis kelamin itu maka spesies manusia dapat terjaga keberlangsungan hidupnya di muka bumi, tanpa adanya kehawatiran punah. Ia juga dijadikan dengan beraneka suku bangsa agar masing-masing mampu mempelajari dan mengenal tradisi yang ada di tengah-tengah mereka. Allah swt. menegaskan dalam al-Qur`an Surat alHujurat: 13:

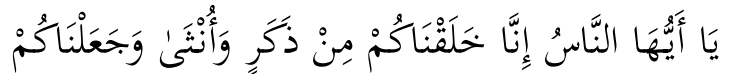

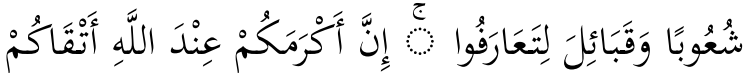

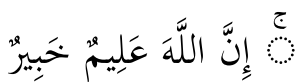

Rangkaian prosesi Nujuh Bulan yang lazim dilakukan masyarakat Muslim Melawi sarat dengan ungkapan rasa syukur dan

9 Muhammad Husein al-Jizani, Ma`alimu Ushul al-Fiqh `inda Ahlis Sunnah wal Jama`ah, Maktabah Syamilah, Ishdar 2, hal. 373 
pengaharapan besar untuk keselamatan calon anak dan ibunya. Pembacaan ayat-ayat al-Qur`an, shalawat dan do`a serta jamuan makanan yang dihidangkan sebagai bentuk shadaqoh dari si empunya hajat, merupakan amalan-amalan islami yang melekat erat pada ritual ini.

Mendo’akan anak keturunan agar menjadi anak yang shalih-shalihah merupakan ajaran Islam yang secara sharih dapat ditemukan dalam al-Qur`an dan hadits. Al-Qur`an telah mencatat bagaimana nabi Ibrahim as mendo`akan anak keturunannya agar menjadi muslim yang berserah diri kepada Allah swt (Q.S. AlBaqarah [2]: 127). Ia juga bermunajat kepada Allah swt agar anak turunannya kelak menjadi orang-orang yang sholih (Q.S. As-Shaffat [37]: 100). Permohonan dan do`a nabi Ibrahim as ini kemudian dikabulkan oleh Allah swt. sehingga dari garis keturuan beliau lahir para nabi dan rasul utusan Allah swt. dan beliau sendiri dinobatkan sebagai bapak para nabi (abu al-anbiyã)).

Selain ayat-ayat al-Quran dan hadits, anjuran untuk senantiasa mendoakan anak sejak dalam kandungan juga banyak dicontohkan oleh para ulama. Diantaranya yang telah dilakukan oleh Imam Ahmad bin Hanbal yang terbiasa mendoakan dan membagi-bagikan hadiah ketika istri beliau yang sedang hamil. Al-Imam Ibn al-Jauzi meriwayatkan dalam kitabnya Manaqib alImam Ahmad bin Hanbal, (406-407), bahwa keluarga al-Imam Ahmad bin Hanbal, membagi-bagikan sedekah ketika istri beliau (al-Imam Ahmad bin Hanbal) hamil.

"Imam al-Khallal berkata, "Kami menerima kabar dari Muhammad bin Ali bin Bahar, berkata, "Aku mendengar Husnu, Ibu yang melahirkan anak-anak al-Imam Ahmad bin Hanbal, berkata, "Aku berkata kepada tuanku (Ahmad bin Hanbal), "Tuanku, bagaimana kalau gelang kaki satu-satunya milikku ini aku sedekahkan?" Ahmad menjawab, "Kamu rela melepasnya?" Aku menjawab, "Ya." Ahmad berkata, "Segala puji bagi Allah yang telah memberimu pertolongan untuk melakukannya." Ниsnu berkata, "Lalu gelang kaki itu aku serahkan kepada Abu al-Hasan bin Shalih dan dijualnya seharga 8 dinar setengah. Lalu uang itu ia bagi-bagikan kepada orangorang pada saat kehamilanku. Setelah aku melahirkan Hasan, tuanku memberi hadiah uang 1 Dirham kepada Karramah, wanita tua yang menjadi pelayan kami ${ }^{10}$."

Imam Ahmad bin Hanbal sebagai pendiri Madzhab Hanbali dan banyak menjadi rujukan kalangan salaf telah mempraktikkan amalan mendo`akan anak keturunannya dan bersedekah pada saat istrinya dalam keadaan hamil. Suatu kebiasaan yang tidak jauh berbeda dengan

\footnotetext{
${ }^{10}$ Ibn al-Jauzi, Manaqib al-Imam Ahmad bin Hanbal, (Maktabah Syamilah Ishdar 2), hal. 406-407.
} 


\section{Al-Hikmah: Jurnal Dakwah, Volume 12, Nomor I, Tahun 2018 \\ [P. 83-100]}

tradisi di kalangan muslim Indonesia saat ini.

Di sisi lain, ketika seseorang di antara kita memiliki bayi dalam kandungan, tentu kita mendambakan agar buah hati kita lahir ke dunia dalam keadaan sempurna, selamat, sehat wal `afiyat dan menjadi anak yang saleh sesuai dengan harapan keluarga dan agama. Para ulama menganjurkan agar kita selalu bersedekah ketika mempunyai hajat yang kita inginkan tercapai.

Dalam hal ini al-Imam al-Hafizh alNawawi -seorang ulama ahli hadits dan ahli fiqih madzhab al-Syafi'i-, berkata:

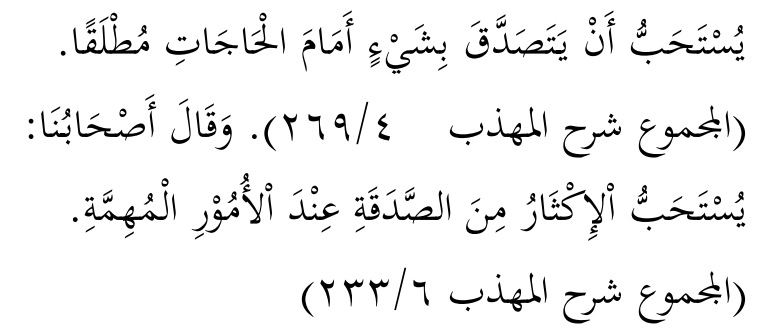

"Disunnahkan bersedekah sekedarnya ketika mempunyai hajat apapun. (al-Majmu' Syarh al-Muhadzdzab, juz 4, hal. 269). Para ulama kami berkata, "Disunnahkan memperbanyak sedekah ketika menghadapi urusan-urusan yang penting. ",11

Berkenaan dengan tradisi dan beberapa jamuan rangkaian ritual yang terdapat pada tradisi nujuh bulan, dalam pandangan fiqih, segala bentuk jamuan yang disungguhkan dan dihidangkan dalam

11 Imam an-Nawawi, al-Majmu` syarhu alMuhazzab, Maktabah Syamilah Ishdar 2, Juz 6 hal. 233. waktu-waktu tertentu, seperti nujuh bulan atau hal-hal lain yang ditujukan sebagai wujud rasa kegembiraan disebut walimah. Menurut madzhab Syafi'i mengadakan perjamuan/hidangan selain untuk walimatul urusy hukumnya sunnah, sebab hidangan tersebut dimaksudkan untuk menampakkan rasa syukur atas kenikmatan dari Allah swt dan dianjurkan juga untuk menghadiri undangan jamuan tersebut dengan tujuan menyambung hubungan baik antar sesama umat Islam atau silaturahmi dengan sesama.

Dilihat dari rangkaian ritual yang dilakukan pada tradisi nujuh bulan merupakan tradisi yang dilakukan dengan cara-cara yang tidak bertentangan dengan syari'at Islam, oleh karena ini diisi dengan pembacaan do'a terhadap janin dalam kandungan dan pemberian sedekah berupa hidangan, yang mana hal tersebut sangat dianjurkan dalam Islam.

Oleh sebab itu, tradisi ini hukumnya boleh dilakukan karna termasuk dalam kategori walimah yang bertujuan untuk menampakkan rasa syukur akan kenikmatan dari Allah swt berupa akan lahirnya seorang bayi. Terlebih lagi apabila hidangan tersebut disuguhkan dengan mengundang orang lain dan diniati untuk sedekah serta sebagai permohonan agar ibu yang mengandung dan 
anak yang dikandungnya diberi keselamatan oleh Allah swt. Para ulama sepakat bahwa member sedekah adalah sunat, apalagi dilakukan pada saat-saat penting seperti bulan Ramadhan.

\section{Pandangan Sosial Mengenai Nujuh Bulan}

Dalam pandangan sosial, tradisi Nujuh Bulan di masyarakat Melayu Kabupaten Melawi memiliki keterkaitan dengan status sosial yang disandang. Semakin meriah acara ini dilakukan, semakin ramai tamu yang diundang, dan semakin banyak makanan yang dihidangkan maka semakin tinggi pula status sosialnya di masyarakat. Namun jika hajatan ini hanya dilakukan dengan sangat sederhana, tidak banyak masyarakat yang diundang dan hidangan yang disuguhkan, maka status sosialnya di masyarakat kurang tinggi.

Sanksi sosial juga akan diberikan oleh masyarakat bagi mereka yang tidak atau enggan melaksanakan tradisi ini. Masyarakat Melayu Melawi memiliki persepsi yang kurang baik terhadap anggota masyarakat yang tidak melakukannya. Mereka beranggapan setiap anggota masyarakat yang tidak mau melakukannya sebagai orang yang kurang menghargai anugrah yang telah diberikan oleh Tuhan, kurang bersyukur dan abai akan tradisi yang telah diwarisi dari nenek moyangnya secara turun temurun.

Oleh sebab itu, setiap anggota masyarakat Melayu Muslim di Melawi akan lebih baik jika tetap melestarikan tradisi tersebut, baik rangkaian kegiatannya diadakan secara meriah, besar-besaran ataupun secara sederhana, daripada tidak dilakukan sama sekali. Karena bagi masyarakat Melayu Kabupaten Melawi acara tersebut sudah menjadi tradisi yang wajib untuk dilakukan. Jika tidak melakukannya maka akan dianggap tidak menghargai tradisi yang sudah dilakukan turun temurun.

\section{KESIMPULAN}

Dalam konteks tradisi Nujuh Bulan memiliki tujuan yang baik, serta subtansi yang terdapat di dalamnya nilai-nilai ajaran Islam. Oleh karena itu, tidak ada larangan yang bersifat syar'i atas keberadaa tradisi semacam ini. Dalam penetapan hukum Islam dikenal salah satu cara melakukan ijtihad yang disebut 'urf, yakni penetapan hukum dengan mendasar pada tradisi yang berkembang dalam masyarakat sekitar. Dengan cara ini berarti tradisi dapat dijadikan dasar penetapan hukum Islam dengan syarat tidak bertentangan dengan 


\section{Al-Hikmah: Jurnal Dakwah, Volume 12, Nomor I, Tahun 2018 \\ [P. 83-100]}

ajaran Islam yang tertuang dalam al-Quran dan hadits Nabi saw.

Islam sangat memperhatikan sekali masalah adat istiadat suatu masyarakat, karena ia dapat mempengaruhi pembentukan hukum tersebut. Maka dari itu, setiap perbuatan yang diterima oleh mayoritas umat Islam, dikategorikan sebagai perbuatan yang baik di sisi Allah swt, sebab tidak mungkin orang banyak bersepakat dalam masalah kejelekan. Setiap adat kebiasaan yang berlaku pada suatu masyarakat serta tidak melanggar ketentuan syariat, harus tetap dipelihara dan diamalkan. Sebaliknya, adat kebiasaan yang menyimpang dari ketentuan syariat, walaupun banyak dikerjakan orang, tetap tidak boleh diamalkan, lantaran di dalam hadits diberi hasanan (baik), yang sudah barang tentu menurut ukuran syar'i dan logika tersebut.

\section{DAFTAR PUSTAKA}

Ahmad Baso, Islam Nusantara, Ijtihad Jenius \& Ijma` Ulama Indonesia. Jilid I, (Tangerang: Pustaka Afid, 2015).

Al-Qur'an dan terjemahan, Al-Hikmah (Bandung: Penerbit Diponegoro, 2008).

Buhori, Islam dan Tradisi Lokal di Nusantara, (Pontianak: Jurnal AlMaslahah IAIN Pontianak, 2017) Vol 13, No. 2.
Dedi Supriyadi, Sejarah Peradaban Islam, (Bandung: Pustaka Setia, 2008).

Departemen Pendidikan Nasional, Kamus Besar Bahasa Indonesia, (Jakarta: Pusat Bahasa, 2008).

Ibn al-Jauzi, Manaqib al-Imam Ahmad bin Hanbal, (Maktabah Syamilah Ishdar 2).

Muhammad Husein al-Jizani, Ma`alimu Ushul al-Fiqh ‘inda Ahlis Sunnah wal Jama`ah, (Maktabah Syamilah, Ishdar 2)

Muslim A. Kadir, Dasar-Dasar Keberagamaan Dalam Islam, (Yoyakarta: PustakaPelajar, 2011).

Riyadh bin Mansur al-Akholifi, Al-Mihhaj fi ilmil Qowa`id alFiqhiyyah, Juz 1 (Maktabah Syamilah, Isdor Tsnai).

Siradjuddin Abbas, 40 Masalah Agama 3, (Jakarta: Pustaka Tarbiyah Baru, 2012). 
Buhori; Hanna Yulia; Velly Pranika Sari:

Tradisi Nujuh Bulan pada Masyarakat Melayu Kabupaten Melawi dalam Perspektif Islam 